The $2{ }^{\text {nd }}$ Conf. of SSFOP "Future of Ornamental Plants in Egypt and Arab World", Cairo, Egypt, 21/2/2016

Scientific J. Flowers \& Ornamental Plants

www.ssfop.com/journal

ISSN: 2356-7864

\title{
EFFECT OF MINERAL AND BIOFERTILIZATION TREATMENTS ON: 2- CORMS PRODUCTIVITY AND CHEMICAL CONSTITUENTS OF GLADIOLUS CV. WHITE PROSPERITY
}

\author{
M.A.H. Abdou ${ }^{*}$, M.A. Mohamed and T.I.E. Ibrahim ${ }^{* *}$ \\ * Hort. Dept., Fac. Agric., Minia Univ., Egypt. \\ ** Ministry of Agriculture, Egypt.
}

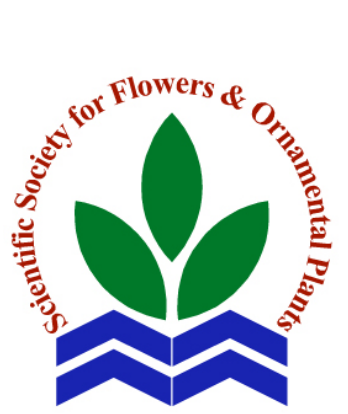

ABSTRACT: A field experiment was conducted at Nursery of Ornamental Plants, Fac. Agric., Minia Univ. during 2013/2014 and $2014 / 2015$ to investigate the effect of NPK $(0,50,75$ and $100 \%$ of recommended dose) and biofertilizers (phosphorein and/or E.M.) on corm and cormels productivity, as well as, chemical constituents of gladiolus cv. White Prosperity.

The obtained results indicated that, corm diameter, corm dry weight, number of cormels/plant, cormels dry weight/plant, as well as, chemical constituents $(\mathrm{N}, \mathrm{P}, \mathrm{K}$ and total sugars \% in corms and total Scientific J. Flowers \& chlorophyll in leaves) were significantly increased with all levels of Ornamental Plants, NPK in comparison with control. The highest values were obtained 3(1):9-17 (2016).

Received: with NPK $100 \%$.

All biofertilizer treatments significantly increased corm and 21/1/2016

Revised by:

Prof. Dr. E.S. Nofal, Kafr El-Sheikh Univ.

Prof. Dr. M.M. Farahat, Agric. \& Biol. Res. Div., NRC. cormels productivity, as well as, either chemical constituents in comparison with the control. Phosphorein + E.M. was more effective in this concern.

The interaction treatments were significant with the highest values being obtained due to NPK 75\% in combination with phosphorein + effective microorganisms (E.M.).

Key words: Gladiolus grandiflorus cv. White Prosperity, NPK, biofertilization, phosphorein, E.M., corms productivity, chemical constituents.

\section{INTRODUCTION}

Gladiolus grandiflorus, L. plant is considered one of the most important flowering bulbs grown in Egypt. Gladiolus plants are propagated by corms and cormels.

The effect of NPK on increasing the corm and cormels productivity, fresh and dry weights of corms and cormels of gladiolus were reported by many investigators such as Pimpini and Zanin (2002); Atta-Alla et al. (2003); Khan and Iftikhar (2004); Butt (2005); Gaurav and Prabhakar (2007); Taha and Hassan (2008) and Kumar (2015).

With regard to chlorophyll content and NPK elements of gladiolus leaves and corms, NPK was found to increase chlorophyll contents and NPK elements (Atta-Alla et al., 2003; Abdou et al., 2004 and Taha and Hassan, 2008).

Biofertilizer treatments were found to have stimulating effects on bulb, corm and cormels productivity and pigments contents, as well as, $\mathrm{N}, \mathrm{P}$ and $\mathrm{K} \%$ as reported by Rajes et al. (2006); Taha and Hassan (2008) and Basoli et al. (2015) on gladiolus; Hussein (2004) and Allam and El-Tayeb (2008) on Iris and Yadav et al. (2011) on tuberose.

The aim of this work was to study the effect of application of NPK fertilization and 
chemical constituents on Gladiolus grandiflorus cv. While Prosperity.

\section{MATERIALS AND METHODS}

The present study was carried out at the Nursery of Ornamental Plants, Fac. Agric., Minia Univ., during the two successive seasons of 2013/2014 and 2014/2015 on corm and cormels production and some chemical constituents of Gladiolus graniflorus cv. White Prosperity.

Gladiolus corms were obtained from Holland by Basiouny nurseries, Cairo, Egypt. Average corm diameter was 2.9 and $3.2 \mathrm{~cm}$ and corm weight was 9.7 and $9.9 \mathrm{~g}$ for the first and second seasons, respectively. Corms were planted on October, $15^{\text {th }}$ for both seasons in $1.8 \times 2 \mathrm{~m}$ plots containing 3 ridges, $50 \mathrm{~cm}$ apart. Corms were planted in hills, $20 \mathrm{~cm}$ apart (8 corms/ridge). Physical and chemical properties of the soil used are listed in Table (a). The split plot design with three replicates was followed in this experiment.

The four combined NPK fertilization treatments were considered as main plots (A) and four biofertilization treatments the subplots (B). The four NPK fertilization treatments were $\mathrm{N}_{0} \mathrm{P}_{0} \mathrm{~K}_{0}$ (0:0:0), $\mathrm{N}_{1} \mathrm{P}_{1} \mathrm{~K}_{1}$ (150:80:100), $\quad \mathrm{N}_{2} \mathrm{P}_{2} \mathrm{~K}_{2} \quad$ (225:120:150), $\mathrm{N}_{3} \mathrm{P}_{3} \mathrm{~K}_{3} \quad$ (300:160:200). Nitrogen fertilization rates of $\mathrm{N}_{0}, \mathrm{~N}_{1}, \mathrm{~N}_{2}$ and $\mathrm{N}_{3}$ were represented by $0,150,225$ and $300 \mathrm{~kg} / \mathrm{fed}$ ammonium nitrate $(33.5 \% \mathrm{~N})$. However, phosphorus was applied at $\mathrm{P}_{0}, \mathrm{P}_{1}, \mathrm{P}_{2}$ and $\mathrm{P}_{3}$ represented by $0,80,120$ and $160 \mathrm{~kg} /$ fed calcium superphosphate $\left(15.5 \% \mathrm{P}_{2} \mathrm{O}_{5}\right)$ and potassium was added at $\mathrm{K}_{0}, \mathrm{~K}_{1}, \mathrm{~K}_{2}$ and $\mathrm{K}_{3}$ represented by $0,100,150$ and $200 \mathrm{~kg} / \mathrm{fed}$ potassium sulphate $\left(48.5 \% \quad \mathrm{~K}_{2} \mathrm{O}\right)$. The combined $\mathrm{N}_{1} \mathrm{P}_{1} \mathrm{~K}_{1}, \mathrm{~N}_{2} \mathrm{P}_{2} \mathrm{~K}_{2}$ and $\mathrm{N}_{3} \mathrm{P}_{3} \mathrm{~K}_{3}$ presented 50, 75 and $100 \%$ respectively.

Phosphorus fertilizer was added before planting during the soil preparation. The amounts of $\mathrm{N}$ and $\mathrm{K}$ mineral fertilization were added at the three equal batches, one month, and two months from planting date and after flower cut for corm and cormels production.

The biofertilization treatments were as follows: (1) Control (without any biofertilizers), (2) Phosphorein, (3) E.M. (effective microorganisms), (4) E.M. + phosphorein.

The biofertilizers were applied three times to the soil beside the plants at 50 ml/plant E.M. or phosphorein. Application was carried out three times, 35 and 70 days after planting and after flower cut for corm and cormels productivity.

The following data were recorded:

1- Underground parts characters at harvesting, after the foliage had been dried (the underground parts were lifted 2 months after cut spikes) corm diameter (cm), corm dry weight (g), number of new cormels/plant and dry weights of new cormels/plant (g).

Table a. Physical and chemical properties of the used soil.

\begin{tabular}{|c|c|c|c|c|}
\hline Soil Character & Value & \multicolumn{2}{|c|}{ Soil Character } & Value \\
\hline Sand \% & 28.20 & \multicolumn{2}{|c|}{ Available P \% } & 15.12 \\
\hline Silt \% & 30.7 & \multicolumn{2}{|c|}{ Exch. $K^{+}$(mg/100 g soil) } & 2.11 \\
\hline Clay \% & 41.10 & \multicolumn{2}{|c|}{ Exch. $\mathrm{Ca}^{++}(\mathrm{mg} / 100 \mathrm{~g}$ soil $)$} & 31.74 \\
\hline Texture grade & Clayey loam & \multicolumn{2}{|c|}{ Exch. $\mathrm{Na}^{+}(\mathrm{mg} / 100$ g soil) } & 2.40 \\
\hline Organic matter \% & 1.62 & \multirow{5}{*}{$\begin{array}{l}\text { DTPA } \\
\text { Ext. ppm }\end{array}$} & Fe & 8.54 \\
\hline $\mathrm{CaCO}_{3} \%$ & 2.09 & & $\mathrm{Cu}$ & 2.06 \\
\hline E.C. (mmhos/cm) & 1.04 & & Zn & 2.75 \\
\hline pH (1:2.5) & 7.82 & & Mn & 8.26 \\
\hline Total N \% & 0.08 & & & \\
\hline
\end{tabular}


2- Determination of some chemical constituents: leaves samples were taken after 75 days from planting, but corms and cormels samples were taken after two months from flowering termination.

- Total chlorophyll (mg/g f.w.) was determined in the fresh leaves samples using the method described by Moran (1982).

- The percentage of $\mathrm{N}, \mathrm{P}$ and $\mathrm{K}$ in the dry corms were estimated according to Page et al. (1982), then the contents of the three elements in the dry corms were calculated.

- Total sugars in the dry corms (mg/g) were determined according to Moore (1974).

All the obtained data were subjected to the statistical analysis of variance using MSTAT-C (1986). L.S.D. test at $5 \%$ was used to compare the average means of treatments.

\section{RESULTS AND DISCUSSION}

\section{1- Corm and cormels productivity:}

Data presented in Tables (1 and 2) during both seasons indicated that corm diameter, corm dry weight, number of cormels/plant and dry weight of cormels were significantly increased with increasing NPK fertilizer levels in comparison with control $\left(\mathrm{N}_{0} \mathrm{P}_{0} \mathrm{~K}_{0}\right)$. The highest level $\left(\mathrm{N}_{3} \mathrm{P}_{3} \mathrm{~K}_{3}\right)$ treatment resulted the highest values for all corms and cormels productivity over the other used treatments in both seasons. Similar results were revealed on gladiolus plants such as those of Pimpini and Zanin (2002), Butt (2005) and Taha and Hassan (2008).

The increase in the corm and cormels productivity was attributed to the positive effect of NPK fertilizer on improving the vegetative growth traits which reflected on increasing the underground organs.

Data presented in Tables (1 and 2) indicated that the three treatments of biofertilizer significantly increased corm diameter, corm dry weight, number of cormels/plant and dry weight of cormels/plant in comparison with the control treatment in both seasons. The treatment of phosphorein + E.M. was more effective than the other two treatments in this concern. Similar observations were pointed out on gladiolus plant, Abdou et al. (2004); Rajes et al. (2006), Taha and Hassan (2008) and Basoli et al. (2015).

The stimulatory effect of biofertilizers on corms and cormels production may be due to the mode of action of biofertilizer on the soil, plant promoting hormone and enzymes, which came from addition of biofertilizers which gave better vegetative growth and better photosynthesis consequently more dry matter accumulation.

The interaction between NPK and biofertilization treatments was significant, in both season, for corm diameter, corm dry weight, number of cormels/plant and cormels dry weight/plant (Tables, 1 and 2). The highest values were obtained when gladiolus cv. White Prosperity plants received either $\mathrm{N}_{3} \mathrm{P}_{3} \mathrm{~K}_{3}$ or $\mathrm{N}_{2} \mathrm{P}_{2} \mathrm{~K}_{2}$ in combination with biofertilizers (phosphorein + E.M.).

\section{2- Chemical constituents:}

\section{a. Total chlorophyll:}

The content of total chlorophyll (mg/g f.w.) was significantly promoted with all NPK treatments in comparison with control $\left(\mathrm{N}_{0} \mathrm{P}_{0} \mathrm{~K}_{0}\right)$. The treatment of $\mathrm{N}_{3} \mathrm{P}_{3} \mathrm{~K}_{3}$ gave the highest content of total chlorophyll in both seasons (Table, 2). These results may be due to the increase in nutrient elements. Similar results were obtained by Abdou et al. (2004), Taha and Hassan (2008) and Abdou et al. (2013) on gladiolus.

Total chlorophyll content was significantly promoted in both seasons comparing with control treatment due to phosphorein and/or E.M. treatments. Using phosphorein plus E.M. was effective in this concern. This result may be attributed to the increase in $\mathrm{N}$ and $\mathrm{P}$ elements and/or plant promoting hormone, which came as a result from inoculation of bacteria, that reflect on 
Table 1. Effect of mineral NPK fertilization and biofertilization treatments on corm diameter (cm), corm dry weight (g) and number of cormels/plant of gladiolus cv. White Prosperity during 2013/2014 and 2014/2015.

\begin{tabular}{|c|c|c|c|c|c|c|c|c|c|c|}
\hline \multirow{3}{*}{$\begin{array}{l}\text { Biofertilization } \\
\text { treatments (B) }\end{array}$} & \multicolumn{10}{|c|}{ NPK fertilization from recommended dose (A) } \\
\hline & \multicolumn{5}{|c|}{$1^{\text {st }}$ season } & \multicolumn{5}{|c|}{$2^{\text {nd }}$ season } \\
\hline & $\mathbf{N}_{\mathbf{0}} \mathbf{P}_{\mathbf{0}} \mathbf{K}_{\mathbf{0}}$ & $\mathbf{N}_{1} \mathbf{P}_{1} \mathbf{K}_{1}$ & $\mathbf{N}_{2} \mathbf{P}_{2} \mathbf{K}_{2}$ & $\mathbf{N}_{3} \mathbf{P}_{3} \mathbf{K}_{3}$ & $\begin{array}{c}\text { Mean } \\
\text { (B) }\end{array}$ & $\mathbf{N}_{\mathbf{0}} \mathbf{P}_{\mathbf{0}} \mathbf{K}_{\mathbf{0}}$ & $\mathbf{N}_{1} \mathbf{P}_{1} \mathbf{K}_{1}$ & $\mathbf{N}_{2} \mathbf{P}_{2} \mathbf{K}_{2}$ & $\mathbf{N}_{3} \mathbf{P}_{3} \mathbf{K}_{3}$ & $\begin{array}{c}\text { Mean } \\
\text { (B) }\end{array}$ \\
\hline \multicolumn{11}{|c|}{ Corm diameter $(\mathrm{cm})$} \\
\hline Control & 3.11 & 3.62 & 4.10 & 4.51 & 3.84 & 3.18 & 3.70 & 4.22 & 4.60 & 3.93 \\
\hline Phosphorein & 3.52 & 4.01 & 4.50 & 4.91 & 4.24 & 3.59 & 4.10 & 4.61 & 5.00 & 4.33 \\
\hline E.M. & 3.81 & 4.32 & 4.80 & 5.21 & 4.54 & 3.90 & 4.40 & 4.91 & 5.21 & 4.61 \\
\hline Phos. + E.M. & 4.22 & 4.71 & 5.22 & 5.64 & 4.95 & 4.23 & 4.74 & 5.24 & 5.69 & 4.98 \\
\hline Mean (A) & 3.67 & 4.17 & 4.66 & 5.07 & & 3.73 & 4.24 & 4.75 & 5.13 & \\
\hline L.S.D. at $5 \%$ & \multicolumn{2}{|c|}{ A: 0.22} & B: 0.21 & \multicolumn{2}{|c|}{ AB: 0.42} & \multicolumn{2}{|c|}{ A: 0.31} & B: 0.23 & \multicolumn{2}{|c|}{$\mathrm{AB}: 0.46$} \\
\hline \multicolumn{11}{|c|}{ Corm dry weight (g) } \\
\hline Control & 10.41 & 12.09 & 13.74 & 15.11 & 12.84 & 10.65 & 12.40 & 14.14 & 15.41 & 13.15 \\
\hline Phosphorein & 11.79 & 13.43 & 15.08 & 16.45 & 14.19 & 12.03 & 13.74 & 15.44 & 16.75 & 14.49 \\
\hline E.M. & 12.76 & 14.47 & 16.07 & 17.45 & 15.19 & 13.06 & 14.73 & 16.45 & 17.41 & 15.41 \\
\hline Phos. + E.M. & 14.12 & 15.77 & 17.49 & 18.90 & 16.57 & 14.17 & 15.87 & 17.56 & 19.07 & 16.67 \\
\hline Mean (A) & 12.27 & 13.94 & 15.60 & 16.98 & & 12.48 & 14.19 & 15.90 & 17.16 & \\
\hline L.S.D. at $5 \%$ & \multicolumn{2}{|c|}{ A: 0.86} & B: 0.72 & \multicolumn{2}{|c|}{ AB: 1.44} & \multicolumn{2}{|l|}{ A: 0.98} & B: 0.82 & \multicolumn{2}{|c|}{$\mathrm{AB}: 1.64$} \\
\hline \multicolumn{11}{|c|}{ Number of cormels/plant } \\
\hline Control & 29.14 & 33.85 & 38.45 & 42.30 & 35.94 & 29.82 & 34.71 & 39.59 & 43.14 & 36.82 \\
\hline Phosphorein & 33.01 & 37.50 & 42.22 & 46.00 & 39.68 & 33.65 & 38.45 & 43.21 & 46.50 & 40.45 \\
\hline E.M. & 35.70 & 40.51 & 44.95 & 48.81 & 42.49 & 36.55 & 41.23 & 46.01 & 48.75 & 43.14 \\
\hline Phos. + E.M. & 39.51 & 44.15 & 48.97 & 52.92 & 46.39 & 39.66 & 44.44 & 49.17 & 53.40 & 46.67 \\
\hline Mean (A) & 34.34 & 39.00 & 43.65 & 47.51 & & 34.92 & 39.71 & 44.50 & 47.95 & \\
\hline L.S.D. at $5 \%$ & \multicolumn{2}{|c|}{ A: 3.11} & B: 2.05 & \multicolumn{2}{|c|}{$\mathrm{AB}: 4.10$} & \multicolumn{2}{|c|}{ A: 3.15} & B: 2.31 & \multicolumn{2}{|c|}{$\mathrm{AB}: 4.62$} \\
\hline
\end{tabular}

Phos.= Phosphorein , E.M.= Effective microorganisms

$N_{0} P_{0} K_{0}=0 \%, N_{1} P_{1} K_{1}=50 \%, N_{2} P_{2} K_{2}=75 \%, N_{3} P_{3} K_{3}=100 \%$ 
Table 2. Effect of mineral NPK fertilization and biofertilization treatments on cormels dry weight (g), total chlorophyll (mg/g f.w.) and corm nitrogen content (mg/g d.w.) of gladiolus cv. White Prosperity during 2013/2014 and 2014/2015.

\begin{tabular}{|c|c|c|c|c|c|c|c|c|c|c|}
\hline \multirow{3}{*}{$\begin{array}{l}\text { Biofertilization } \\
\text { treatments (B) }\end{array}$} & \multicolumn{10}{|c|}{ NPK fertilization from recommended dose (A) } \\
\hline & \multicolumn{5}{|c|}{$1^{\text {st }}$ season } & \multicolumn{5}{|c|}{$2^{\text {nd }}$ season } \\
\hline & $\mathbf{N}_{\mathbf{0}} \mathbf{P}_{\mathbf{0}} \mathbf{K}_{0}$ & $\mathbf{N}_{1} \mathbf{P}_{1} \mathbf{K}_{1}$ & $\mathbf{N}_{2} \mathbf{P}_{2} \mathbf{K}_{2}$ & $\mathbf{N}_{3} \mathbf{P}_{3} \mathbf{K}_{3}$ & $\begin{array}{c}\text { Mean } \\
\text { (B) }\end{array}$ & $\mathbf{N}_{0} \mathbf{P}_{0} \mathbf{K}_{0}$ & $\mathbf{N}_{1} \mathbf{P}_{1} \mathbf{K}_{1}$ & ${ }_{1} \mathbf{N}_{2} \mathbf{P}_{2} \mathbf{K}_{2}$ & $\mathbf{N}_{3} \mathbf{P}_{3} \mathbf{K}_{3}$ & $\begin{array}{c}\text { Mean } \\
\text { (B) }\end{array}$ \\
\hline \multicolumn{11}{|c|}{ Cormels dry weight (g) } \\
\hline Control & 11.05 & 11.93 & 13.41 & 14.84 & 12.81 & 11.28 & 13.10 & 15.01 & 18.23 & 14.41 \\
\hline Phosphorein & 11.56 & 12.45 & 13.95 & 15.30 & 13.32 & 11.79 & 13.65 & 15.55 & 18.71 & 14.93 \\
\hline E.M. & 12.45 & 13.36 & 14.88 & 16.22 & 14.23 & 12.79 & 14.56 & 16.46 & 19.62 & 15.86 \\
\hline Phos. + E.M. & 13.56 & 14.40 & 16.95 & 17.75 & 15.54 & 13.89 & 15.56 & 19.88 & 20.59 & 17.50 \\
\hline Mean (A) & 12.16 & 13.04 & 14.80 & 15.90 & & 12.44 & 14.24 & 16.73 & 19.29 & \\
\hline L.S.D. at $5 \%$ & \multicolumn{2}{|c|}{ A: 0.88} & B: 0.51 & \multicolumn{2}{|c|}{$\mathrm{AB}: 1.01$} & \multicolumn{2}{|c|}{ A: 1.12} & B: 0.47 & \multicolumn{2}{|c|}{$\mathrm{AB}: 0.94$} \\
\hline \multicolumn{11}{|c|}{ Total chlorophyll (mg/g f.w.) } \\
\hline Control & 3.828 & 3.869 & 3.905 & 3.948 & 3.888 & 3.837 & 3.878 & 3.920 & 3.958 & 3.898 \\
\hline Phosphorein & 3.915 & 3.965 & 4.008 & 4.045 & 3.983 & 3.935 & 3.979 & 4.021 & 4.055 & 3.998 \\
\hline E.M. & 4.020 & 4.070 & 4.105 & 4.149 & 4.086 & 4.040 & 4.080 & 4.122 & 4.158 & 4.100 \\
\hline Phos. + E.M. & 4.221 & 4.275 & 4.315 & 4.351 & 4.291 & 4.241 & 4.185 & 4.328 & 4.361 & 4.279 \\
\hline Mean (A) & 3.996 & 4.045 & 4.083 & 4.123 & & 4.013 & 4.031 & 4.098 & 4.133 & \\
\hline L.S.D. at $5 \%$ & \multicolumn{2}{|c|}{ A: 0.035} & \multicolumn{2}{|l|}{ B: 0.092} & B: 0.184 & \multicolumn{2}{|c|}{ A: 0.017} & B: 0.100 & \multicolumn{2}{|c|}{ AB: 0.200} \\
\hline \multicolumn{11}{|c|}{ Corm nitrogen content (mg/g d.w.) } \\
\hline Control & 111.5 & 152.0 & 193.1 & 224.1 & 170.2 & 116.1 & 158.3 & 196.8 & 225.0 & 174.1 \\
\hline Phosphorein & 126.4 & 168.3 & 208.9 & 238.0 & 185.4 & 132.0 & 174.1 & 211.1 & 240.0 & 189.3 \\
\hline E.M. & 147.0 & 190.5 & 229.1 & 259.2 & 206.4 & 153.0 & 195.2 & 231.9 & 260.0 & 210.0 \\
\hline Phos. + E.M. & 159.1 & 201.0 & 262.1 & 271.3 & 223.4 & 164.1 & 206.3 & 264.1 & 270.1 & 226.2 \\
\hline Mean (A) & 136.0 & 178.0 & 223.3 & 248.2 & & 141.3 & 183.5 & 226.0 & 248.8 & \\
\hline L.S.D. at $5 \%$ & \multicolumn{2}{|c|}{ A: 21.8} & B: 4.7 & \multicolumn{2}{|c|}{ AB: 9.4} & \multicolumn{2}{|c|}{ A: 22.1} & B: 4.1 & \multicolumn{2}{|c|}{ AB: 8.2} \\
\hline
\end{tabular}

Phos. $=$ Phosphorein , E.M. $=$ Effective microorganisms

$N_{0} P_{0} K_{0}=0 \%, N_{1} P_{1} K_{1}=50 \%, N_{2} P_{2} K_{2}=75 \%, N_{3} P_{3} K_{3}=100 \%$ 
Table 3. Effect of mineral NPK fertilization and biofertilization treatments on corm phosphorus content (mg), corm potassium content (mg) and corm total sugars content (mg/g d.w.) of gladiolus cv. White Prosperity during 2013/2014 and 2014/2015.

\begin{tabular}{|c|c|c|c|c|c|c|c|c|c|c|}
\hline \multirow{3}{*}{$\begin{array}{l}\text { Biofertilization } \\
\text { treatments (B) }\end{array}$} & \multicolumn{10}{|c|}{ NPK fertilization from recommended dose (A) } \\
\hline & \multicolumn{5}{|c|}{$1^{\text {st }}$ season } & \multicolumn{5}{|c|}{$2^{\text {nd }}$ season } \\
\hline & \multicolumn{2}{|c|}{$\mathbf{N}_{0} \mathbf{P}_{0} \mathbf{K}_{0} \mathbf{N}_{1} \mathbf{P}_{1} \mathbf{K}$} & $\mathbf{N}_{2} \mathbf{P}_{2} \mathbf{K}_{2}$ & $\mathbf{N}_{3} \mathbf{P}_{3} \mathbf{K}_{3}$ & $\begin{array}{c}\text { Mean } \\
\text { (B) }\end{array}$ & \multicolumn{2}{|c|}{$\mathbf{N}_{0} \mathbf{P}_{0} \mathbf{K}_{0} \mathbf{N}_{1} \mathbf{P}_{1} K_{1}$} & \multicolumn{2}{|c|}{${ }_{1} \mathbf{N}_{2} \mathbf{P}_{2} K_{2} \mathbf{N}_{3} P_{3} K_{3}$} & \multirow[t]{2}{*}{$\begin{array}{c}\text { Mean } \\
\text { (B) }\end{array}$} \\
\hline \multicolumn{10}{|c|}{ Corm phosphorus content (mg/g d.w.) } & \\
\hline Control & 30.1 & 35.2 & 39.4 & 42.1 & 36.7 & 31.1 & 36.8 & 40.5 & 43.3 & 37.9 \\
\hline Phosphorein & 33.6 & 39.0 & 41.5 & 45.0 & 39.8 & 34.0 & 39.1 & 43.6 & 45.9 & 40.7 \\
\hline E.M. & 34.5 & 40.1 & 42.7 & 46.3 & 40.9 & 34.9 & 40.5 & 45.8 & 46.3 & 41.9 \\
\hline Phos. + E.M. & 36.1 & 42.2 & 46.9 & 48.0 & 43.3 & 37.0 & 42.6 & 47.1 & 48.9 & 43.9 \\
\hline Mean (A) & 33.6 & 39.1 & 42.6 & 45.4 & & 34.3 & 39.8 & 44.3 & 46.1 & \\
\hline L.S.D. at $5 \%$ & A: 2 & & B: 0.85 & & B: 1.7 & A: 1.8 & & B: 1.3 & & 3: 2.6 \\
\hline \multicolumn{11}{|c|}{ Corm potassium content (mg/g d.w.) } \\
\hline Control & 71.1 & 90.3 & 109.4 & 119.5 & 97.6 & 72.3 & 94.5 & 110.1 & 121.1 & 99.3 \\
\hline Phosphorein & 91.0 & 113.6 & 127.5 & 137.0 & 117.3 & 92.1 & 115.7 & 130.0 & 140.0 & 119.5 \\
\hline E.M. & 88.5 & 110.4 & 125.1 & 135.6 & 114.9 & 90.2 & 111.8 & 127.4 & 137.8 & 116.8 \\
\hline Phos. + E.M. & 93.1 & 115.8 & 138.9 & 141.8 & 122.4 & 94.5 & 118.9 & 140.1 & 145.6 & 124.8 \\
\hline Mean (A) & 85.9 & 107.5 & 125.2 & 133.5 & & 87.3 & 110.2 & 126.9 & 136.1 & \\
\hline L.S.D. at $5 \%$ & $A: 5$ & & $\mathrm{~B}: 2.9$ & & B: 5.8 & A: 6.8 & & B: 4.0 & & B: 8.0 \\
\hline \multicolumn{11}{|c|}{ Corm total sugars content (mg/g d.w.) } \\
\hline Control & 42.1 & 47.2 & 50.1 & 52.6 & 48.0 & 43.7 & 48.4 & 51.3 & 53.5 & 49.2 \\
\hline Phosphorein & 43.9 & 48.8 & 51.3 & 53.8 & 49.5 & 44.9 & 50.1 & 52.9 & 54.9 & 50.7 \\
\hline E.M. & 44.9 & 50.8 & 53.6 & 55.9 & 51.3 & 46.4 & 52.2 & 54.8 & 56.5 & 52.5 \\
\hline Phos. + E.M. & 47.8 & 53.5 & 59.1 & 63.8 & 56.1 & 49.5 & 55.8 & 59.5 & 65.9 & 57.7 \\
\hline Mean (A) & 44.7 & 50.1 & 53.5 & 56.5 & & 46.1 & 51.6 & 54.6 & 57.7 & \\
\hline L.S.D. at $5 \%$ & $A: 2$ & & B: 3.9 & & B: 7.8 & A: 3.1 & & B: 4.6 & & 3: 9.2 \\
\hline
\end{tabular}

Phos.= Phosphorein , E.M.= Effective microorganisms

$N_{0} P_{0} K_{0}=0 \%, N_{1} P_{1} K_{1}=50 \%, N_{2} P_{2} K_{2}=75 \%, N_{3} P_{3} K_{3}=100 \%$ 
chlorophyll content. Similar results were obtained by Abdou et al. (2004) and Taha and Hassan (2008) on gladiolus.

The interaction between main and sub plot was significant in both seasons with the highest values being obtained with either $\mathrm{N}_{3} \mathrm{P}_{3} \mathrm{~K}_{3}$ or $\mathrm{N}_{2} \mathrm{P}_{2} \mathrm{~K}_{2}$ in combination with phosphorein + E.M.

\section{b. Corms nitrogen, phosphorus, potassium and total sugars content:}

Data presented in Tables (2 and 3) revealed that increasing the levels of NPK fertilizers linearly enhanced the contents of $\mathrm{N}, \mathrm{P}, \mathrm{K}$ and total sugars in the corms of gladiolus. The treatment with high level NPK $\left(\mathrm{N}_{3} \mathrm{P}_{3} \mathrm{~K}_{3}\right)$ gave the highest contents. These results are in agreement with those obtained Atta-Alla et al. (2003), Abdou et al. (2004) and Taha and Hassan (2008) on gladiolus.

Supplying gladiolus with additional NPK fertilizer dose after flowering had been ceased could stimulate and increase the dry matter production in storage organs of flowering bulbs (Mengel and Kirkby, 1987). Moreover, the NPK fertilizers increased the root system, which became more capable of absorption of more amounts of $\mathrm{N}, \mathrm{P}$ and $\mathrm{K}$ elements (Gabra, 2004).

Data also, showed that N, P, K and total sugars contents of corms were significantly increased in the two seasons, as a result of treating gladiolus plants with biofertrilizer treatments in comparison with control (Tables, 2 and 3). The highest contents were obtained when phosphorein and E.M. were used together. The stimulatory effect of biofertilizer on $\mathrm{N}, \mathrm{P}$ and $\mathrm{K}$ contents may be due to the increment of these elements in the root zone from inoculation with phosphorein and/or E.M., that improved the uptake of such elements (Yadav et al., 2011).

The interaction between main and sub plots treatments $(\mathrm{A} \times \mathrm{B})$ was significant, in both seasons, for corm contents of N, P, K and total sugars (Tables, 2 and 3 ). The highest contents for the four constituents were obtained due to $\mathrm{N}_{3} \mathrm{P}_{3} \mathrm{~K}_{3}$ or $\mathrm{N}_{2} \mathrm{P}_{2} \mathrm{~K}_{2}$ in combination with phosphorein + E.M.

\section{REFERENCES}

Abdou, M.A.H.; Aly, M.K. and Ahmed, A.S. (2013). Effect of compost, biofertilization and some vitamins addition on Gladiolus grandiflorus. J. Plant Production, Mansoura Univ., 4(12):1751-1761.

Abdou, M.A.H.; Attia, F.; Aly, M.K. and ElSayed I.H. (2004). Response of gladiolus plants to some bio. and chemical fertilization treatments. 1- Vegetative growth and flowering. Proc. The fifth Arabian Hort. Con. Ismailia, Egypt, 2428 March, 1:50-62.

Allam, Samira S. and El-Tayeb, H.F. (2008). A comparative study for the effect of chemical and biofertilizers on growth, flowering, bulb productivity and chemical composition of Iris tingitana cv. Wedegwood plant. Alex. J. Agric. Res., 53(2):63-70.

Atta-Alla, H.K.; Zaghloul, M.A.; Barka, M. and Hashish, K.H. (2003). Effect of organic manure and NPK fertilizers on the vegetative growth, flowering, bulb productivity and chemical composition of some gladiolus cultivars. Annals of Agric. Sci., Moshtohor, 41(2):889-912.

Basoli, M.; Kumar, P. and Kumar, S. (2015). Impact of integrated nutrient management on post-harvest and corm characters of gladiolus cv. Novalux. Annals of Horticulture, 7(2):109-114.

Butt, S.J. (2005). Effect of N, P and K on some flower quality and corm yield characteristics of gladiolus. J. of Tekirdag Agric. Fac., 2 (3):212-214.

Gabra, G.W.R. (2004). Physiological Studies on Some Ornamental Plants. M.Sc. Thesis, Fac. Agric., Kafr El-Sheikh, Tanta Univ. Egypt. 
Gaurav, S. and Prabhakar, S. (2007). Response of $\mathrm{N}, \mathrm{P}$ and $\mathrm{K}$ on vegetative growth, flowering and corm production in gladiolus under mango orchard. J. of Ornamental Horticulture, 10(1):52-54.

Hussein, H.S.M. (2004). Physiological Studies on Iris Plants. M.Sc. Thesis., Fac. Agric. Cairo Univ. Fgypt.

Khan, M.A. and Iftikhar, A. (2004). Growth and flowering of Gladiolus hortulants, L. cv. Wind Song as influenced by various levels of NPK. Int. J. of Agric. and Biol., 6(6):1037-1039.

Kumar, M. (2015). Flower and corm production in gladiolus cv. Peater Pears as influenced by different nutrients sources. Annals of Horticulture, 8(1):99102.

Mengel, K. and Kirkby, A. (1987). Principles of Plant Nutrition. $4^{\text {th }}$ Ed International Potash, Institute, Bern/ Switzerland.

Moore, T.C. (1974). Research Experiences in Plant Physiology, A Laboratory Manual, Springer Verleg, Berlin, Heidelberg, New York, p.: 247-257.

Moran, R. (1982). Formula determination of chlorophylls pigments extracted with $\mathrm{N}$ dimethyl-formamide. Plant Physiol., 69:1376-1381.
MSTAT-C (1986). A Microcomputer Program for the Design, Management and Analysis of Agronomic Research Experiments (Version 4.0), Michigan Stat Univ., U.S.

Page, A.L.; Miller, R.H. and Kenney, D.R. (1982). Methods of Soil Analysis, Part II. Amer. Soc. Agron. Inc., Madison, Wisconism, USA.

Pimpini, F. and Zanin, G. (2002). Gladiolus, Effect of soil type and fertilizer. Culture. Protette. 31(9):107-114. (C.F. www.beds.ac.uk).

Rajes, B.; Priyanka, K.; Dhiman, S.R. and Ritu, J. (2006). Effect of biofertilizers and biostimulants on growth and flowering in gladiolus J. of Ornamental Horticulture, 9(4):248-252.

Taha, R.A. and Hassan, A.H. (2008). Response of gladiolus plants to mineral and biofertilization treatments. 1Vegetative growth and flowering. Alex. J. Agric. Res., 53 Special Issue: 79-86.

Yadav, B.S.; Sukhbir, I.; Gupta, A.K. and Sehrawat, S.K. (2011). Influence of nitrogen and biofertilizers on nutrients content in tuberose cv. Double at flowering stage. Haryana J. of Hort. Sci., 41(2):85-86.

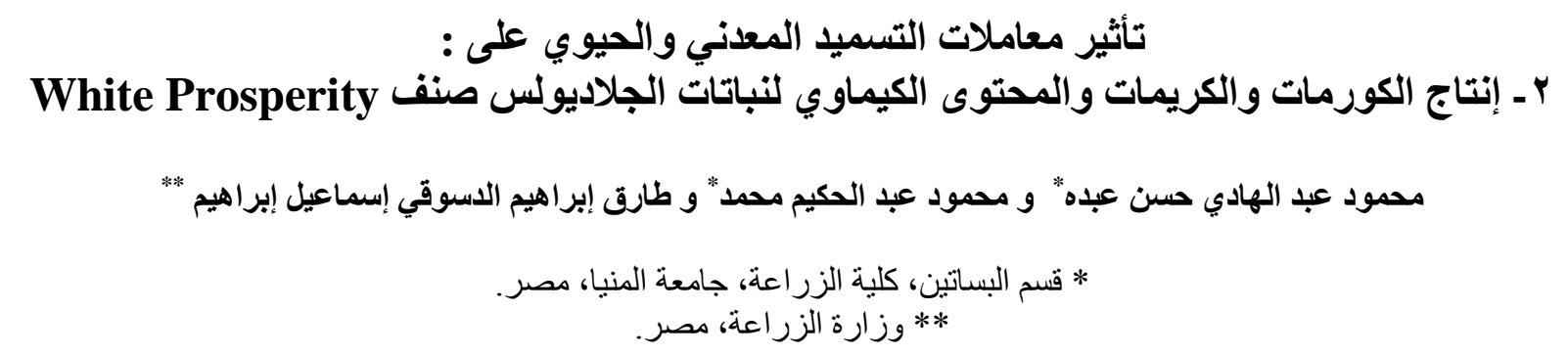

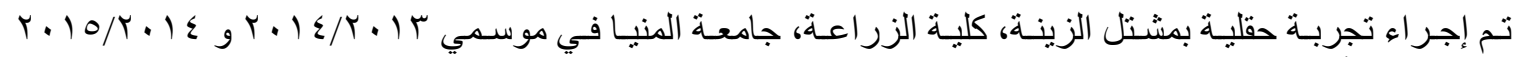

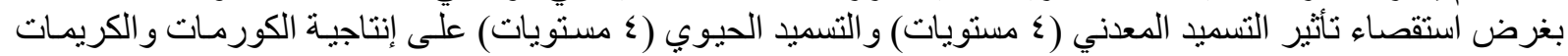

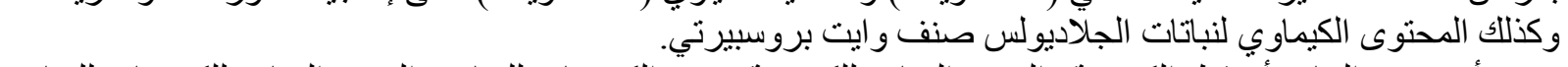

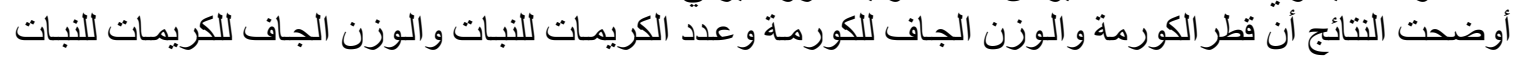

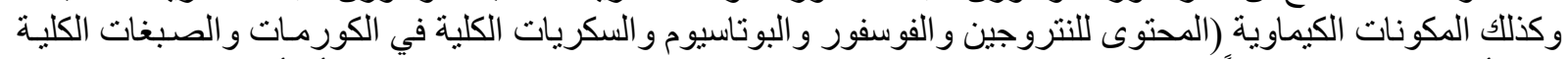

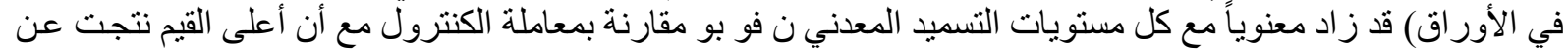
المستوى العالي من التسمبد المعدني. 


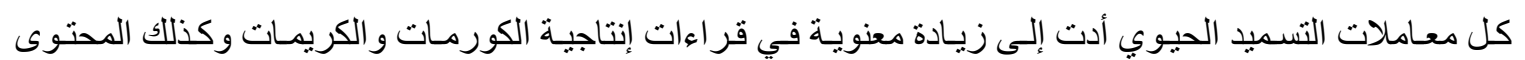
الكيماوي مقارنة بمعاملة الكنترول معاملة الفوسفورين + الميكروبـات الدقيقة النشطة (E.M. كانت التئن أكثر فاعلية في هذا

تأثير معاملات التفاعل كان معنويأ مع أحسن القيم تم الحصول عليها مع استخدام التسمبد المعدني ن فو بو بالمستوى الثأن. المنوسط مع خليط من الفوسفورين و الميكروبات الدقيقة النياعة النشطة. 


